Vol 5 No 1 Maret 2018

\title{
Keterlibatan Pejabat Notaris Terhadap Perbuatan Melawan Hukum Dan Turut Serta Melakukan Tindak Kejahatan Dalam Pemalsuan Dokumen
}

\author{
Abdul Jalal ${ }^{*}$, Suwitno** , Sri Endah Wahyuningsih ${ }^{* *}$ \\ * Mahasiswa Program Magister (S2) Kenotariatan Fakultas Hukum UNISSULA, Semarang email : e-mail \\ abduljalal@gmail.com \\ ** Mahasiswa Program Magister (S2) Ilmu Hukum, Fakultas Hukum UNISSULA, Semarang, e-mail: \\ witno.polri@gmail.com \\ Dosen Fakultas Hukum UNISSULA
}

\begin{abstract}
ABSTRAK
Tujuan penelitian ini adalah untuk menganalisis keterlibatan pejabat notaris terhadap perbuatan melawan hukum dan turut serta melakukan tindak kejahatan dalam pemalsuan dokumen dan menganalisis pertanggungjawaban atas keterlibatan pejabat notaris terhadap perbuatan melawan hukum dan turut serta melakukan tindak kejahatan dalam pemalsuan dokumen

Penelitian ini adalah dengan pendekatan yuridis-normatif yang bersumber dari pengumpulan data yang diperoleh dari data primer dan data sekunder, kemudian dianalisis dengan metode analisis kualitatif. Teknik pengumpulan data yang digunakan adalah studi kepustakaan (undang-undang, pendapat para ahli dan literatur-literatur buku mengenai penelitian ini). Teknik analisis data menggunakan analisis data kualitatif.

Hasil temuan peneliti menunjukkan bahwa akibat hukum bagi notaris yang melakukan pemalsuan dokumen yaitu pihak penghadap/korban mengalami derita kerugian atas terbuatnya suatu akta yang mengandung keterangan palsu oleh notaris. Akta palsu yang telah dibuat dapat dibatalkan. Pembatalan akta adalah menjadi kewenangan hakim perdata, yakni dengan mengajukan gugatan secara perdata kepengadilan serta menurut Undang-Undang Jabatan Notaris (UUJN) dapat dikenakan Sanksi Administratif/Pelanggaran Kode Etik Profesi Notaris berupa teguran lisan, tertulis sampai dengan pemberhentian dengan tidak hormat dari Majelis Pengawas dan Sanksi Keperdataan pasal 1365 KUHPerdata tentang ganti kerugian. Pertanggungjawaban pidana bagi seorang notaris apabila terbukti notaris melakukan tindak pidana pemalsuan surat maka notaris bertanggungjawab secara pribadi atas apa yang menjadi tugas serta kewenangnnya. Berkaitan dengan pertanggungjawaban pidana, seorang notaris dapat dikenakan pidana penyertaaan yang ada pada pasal 55 dan pasal 56 angka (1) dan (2), akibat kelalaiannya atas pmalsuan surat yang dilakukan oleh pekerja notaris.

Kata Kunci : Notaris, Tindak Pidana, Pemalsuan Dokumen.
\end{abstract}

\section{ABSTRACT}

The purpose of this study is to analyze the involvement of notary officials against unlawful acts and participate in committing crimes in falsifying documents and analyzing the accountability of the involvement of notary officials against unlawful acts and taking part in committing crimes in the forgery of documents

This research is a juridical-normative approach that comes from collecting data obtained from primary data and secondary data, then analyzed by qualitative analysis method. Data collection techniques used are literature studies (laws, expert opinions and book literature on this thesis). Data analysis techniques used qualitative data analysis.

The findings of the researcher indicate that the legal consequences for the notary who do forgery of the document that the victim / victim suffers from the loss of a deed containing false information by the notary. Fake deeds that have been created can be canceled. The cancellation of the deed shall be the jurisdiction of civil judges, namely by filing a civil lawsuit as well as according to the Notary Law (UUJN) Law may be liable to Administrative Sanctions / Violations of the Notary Profession Code of Ethics in the form of oral reprimands, written up to disrespectful discharge from the Supervisory Board and Civil Sanction article 1365 Civil Code about compensation. Criminal liability for a notary if a notary is found to have committed a fraudulent crime of a letter, the notary is personally liable for his or her duties and responsibilities. With regard to criminal liability, a notary may be subject to criminal sanction in article 55 and article 56 numbers (1) and (2), due to his negligence on the counterfeit letters made by notary workers.

Keywords: Notary, Crime, Document Fraud. 
perjanjian yang diterapkan. Perjanjian tersebut makin berkembang seiring dengan perkembangan zaman, untuk mendapatkan kepastian dan perlindungan hukum masyarakat menuangkan perjanjian tersebut kedalam akta otentik.

Notaris adalah pejabat umum yang berwenang membuat akta otentik dan kewenangan lainnya sebagaimana dimaksud dalam Undang-Undang nomor 2 Tahun 2014 atas perubahan UndangUndang Nomor 30 tahun 2004 tentang Jabatan Notaris (selanjutnya disebut UUJNP). Di dalam penjelasannya disebutkan bahwa Notaris adalah pejabat umum yang berwenang untuk membuat akta otentik sejauh pembuatan akta otentik tertentu tidak dikhususkan bagi pejabat umum lainnya.

Perlunya perjanjian-perjanjian tertulis dibuat dihadapan seorang notaris adalah untuk menjamin kepastian hukum serta untuk memenuhi hukum pembuktian yang kuat bagi para pihak yang melakukan perjanjian.

Wewenang membuat akta otentik ini hanya dilaksanakan oleh Notaris sejauh pembuatan akta otentik tertentu tidak dikhususkan bagi pejabat umum lainnya ${ }^{1 .}$ Dapat disimpulkan bahwa Notaris adalah satu-satunya pejabat umum yang memiliki wewenang untuk itu.

Mengetahui pentingnya tugas dan kedudukan Notaris di tengah-tengah masyarakat dan kekuatan pembuktian dari akta otentik yang dibuatnya, dapat dikatakan bahwa jabatan Notaris merupakan jabatan kepercayaan. Jabatan kepercayaan yang diberikan undang-undang dan masyarakat ini mewajibkan seseorang yang berprofesi sebagai Notaris bertanggung jawab untuk melaksanakan kepercayaan tersebut dengan sebaik-baiknya serta menjunjung tinggi etika hukum, martabat serta keluhuran jabatannya.

Notaris seringkali dalam praktiknya terlibat dengan perkara hukum baik sebagai saksi maupun sebagai tersangka. ${ }^{2}$ Keterlibatan Notaris dalam perkara hukum disebabkan adanya kesalahan pada akta yang dibuatnya, baik karena kesalahan Notaris itu sendiri maupun kesalahan para pihak atau salah satu pihak yang tidak memberikan keterangan atau dokumen yang sebenarnya (tidak adanya iktikad baik dari para pihak atau salah satu pihak) atau telah ada kesepakatan antara Notaris dengan salah satu pihak yang menimbulkan kerugian pada pihak lain (Notaris turut serta melakukan tindak kejahatan).

\footnotetext{
${ }^{1}$ Habib Adjie, 2009, Hukum Notaris Indonesia (Tafsir Tematik Terhadap Undang-Undang Jabatan Nomor 30 Tahun 2004 Tentang Jabatan Notaris, Cetakan 2, Bandung : PT.Refika Aditama, hlm. 40

${ }^{2}$ Mulyoto, 2010, Kesalahan Notaris dalam Pembuatan Akta Perubahan Dasar CV. Jakarta: Cakrawala Media, hlm. 2
}

Berhubungan dengan akta yang dibuatnya, Notaris harus dimintakan pertanggungjawaban pidananya karena menimbulkan kerugian bagi para pihak atau salah satu pihak ${ }^{3 .}$ Notaris pada dasarnya tidak dapat dimintakan pertanggungjawaban pidana, karena Notaris hanya bertanggung jawab pada sisi formal pembuatan akta. ${ }^{4}$ Terkait hal tersebut jika adanya dugaan keterlibatan pejabat Notaris terhadap perbuatan melawan hukum dan turut serta melakukan kejahatan dalam pemalsuan dokumen. Yang mana dalam hukum di Indonesia pemalsuan terhadap sesuatu merupakan salah satu bentuk tindak pidana yang telah diatur dalam kitab undangundang hukum pidana (KUHP). Ketentuan mengenai turut melakukan dan membantu melakukan dapat dilihat dalam Pasal 55 (turut melakukan) dan Pasal 56 Kitab Undang-Undang Hukum Pidana ("KUHP) (membantu melakukan):

Pasal 55 KUHP:

1) Dihukum sebagai orang yang melakukan peristiwa pidana:

1e.Orang yang melakukan, yang menyuruh melakukan, atau turut melakukan perbuatan itu;

2e.Orang yang dengan pemberian, perjanjian, salah memakai kekuasaan atau pengaruh, kekerasan, ancaman atau tipu daya atau dengan memberi kesempatan, daya upaya atau keterangan, sengaja membujuk untuk melakukan sesuatu perbuatan.

2) Tentang orang-orang yang tersebut dalam sub 2e itu yang dipertanggungjawabkan kepadanya hanyalah perbuatan yang dengan sengaja dibujuk oleh mereka itu, serta dengan akibatnya.

Pasal 56 KUHP:

Dihukum sebagai orang yang membantu melakukan kejahatan:

1) Barangsiapa dengan sengaja membantu melakukan kejahatan itu;

2) Barangsiapa dengan sengaja memberikan kesempatan, daya upaya, atau keterangan untuk melakukan kejahatan itu.

R. Soesilo dalam bukunya yang berjudul Kitab Undang-Undang Hukum Pidana (KUHP) Serta Komentar-Komentarnya Lengkap Pasal Demi Pasal ${ }^{5}$ menjelaskan mengenai apa yang dimaksud

\footnotetext{
${ }^{3}$ Ira Koesoemawati dan Yunirman Rijan, 2009, Ke Notaris, Jakarta : Raih Asa Sukses (RAS), hlm. 82

${ }^{4}$ Pieter Latumaten, 2009, Kebatalan dan Degredasi Kekuatan Bukti Akta Notaris Serta Model Aktanya, Makalah yang disampaikan pada Kongres XX Ikatan Notaris Indonesia di Surabaya.

${ }^{5}$ R. Soesilo. 1991. Kitab Undang-Undang Hukum Pidana (KUHP) Serta Komentar-Komentarnya Lengkap Pasal Demi Pasal. Jakarta : Politeia.
} 
dengan "orang yang turut melakukan" (medepleger) dalam Pasal 55 KUHP. Menurut R. Soesilo, "turut melakukan" dalam arti kata "bersamasama melakukan". Sedikit-dikitnya harus ada dua orang, ialah orang yang melakukan (pleger) dan orang yang turut melakukan (medepleger) peristiwa pidana. Di sini diminta bahwa kedua orang itu semuanya melakukan perbuatan pelaksanaan, jadi melakukan anasir atau elemen dari peristiwa tindak pidana itu. misalnya hanya melakukan perbuatan persiapan saja atau perbuatan yang sifatnya hanya menolong, sebab jika demikian, maka orang yang menolong itu tidak masuk "medepleger" akan tetapi dihukum sebagai "membantu melakukan" (medeplichtige) dalam Pasal 56 KUHP. Sedangkan mengenai Pasal 56 KUHP, R. Soesilo menjelaskan bahwa orang "membantu melakukan" jika ia sengaja memberikan bantuan tersebut, pada waktu atau sebelum (jadi tidak sesudahnya) kejahatan itu dilakukan. Bila bantuan itu diberikan sesudah kejahatan itu dilakukan, maka orang tersebut melakukan perbuatan "sekongkol" atau "tadah" melanggar Pasal $480 \mathrm{KUHP}$, atau peristiwa pidana yang tersebut dalam Pasal $221 \mathrm{KUHP}$.

Dalam penjelasan Pasal 56 KUHP ini dikatakan bahwa elemen "sengaja" harus ada, sehingga orang yang secara kebetulan dengan tidak mengetahui telah memberikan kesempatan, daya upaya, atau keterangan untuk melakukan kejahatan itu tidak dihukum. "Niat" untuk melakukan kejahatan itu harus timbul dari orang yang diberi bantuan, kesempatan, daya upaya atau keterangan itu. Jika niatnya itu timbul dari orang yang memberi bantuan sendiri, maka orang itu bersalah berbuat "membujuk melakukan" (uitlokking).

Kedudukan seorang notaris sebagai fungsionaritas dalam masyarakat dianggap sebagai seorang pejabat tempat seorang dapat memperoleh nasihat yang boleh diandalkan dan pembuatan dokumen yang kuat dalam suatu proses hukum. Masyarakat membutuhkan seorang (figure) yang ketentuan-ketentuannya dapat diandalkan, dapat dipercaya, yang tanda tangannya serta segalanya (capnya) memberikan jaminan dan bukti kuat, seorang ahli yang tidak memihak dan penasihat yang tidak ada cacatnya (onkreukbaar atau unimpeachable), yang tutup mulut, dan membuat suatu perjanjian yang dapat melindunginya di hari yang akan datang. ${ }^{6}$

Notaris yang membuat akta otentik sebagaimana dimaksud di atas meskipun ia tidak terlibat dalam pemalsuan keterangan dalam

\footnotetext{
${ }^{6}$ Kie, Tan Thong. 2000. Studi Notariat Serba Serbi Praktek
} Notaris, Jakarta : Ichtiar Baru Van Hoeve, hlm. 162 pemalsuan akta otentik tersebut dapat saja dilakukan pemanggilan oleh pihak penyidik Polri dalam kapasitasnya sebagai saksi ataupun sebagai keterangan ahli yang dihadirkan di pengadilan. ${ }^{7}$ Bila dalam penyelidikan dan penyidikan pihak kepolisian ternyata didapati bukti permulaan yang cukup atas keterlibatan Notaris dalam memasukkan keterangan palsu dalam akta otentik yang dibuatnya tersebut, maka tidak tertutup kemungkinan Notaris tersebut dapat dijadikan tersangka.

UUJN dan UU Perubahan atas UUJN tidak mengatur mengenai tanggungjawab pidana seorang notaris dari akta yang telah dibuatnya berdasarkan data dan informasi yang dipalsukan oleh para pihak. Sehingga timbul kekosongan norma hukum dalam UU Perubahan atas UUJN yang berkaitan dengan tanggung jawab notaris dalam pembuatan akta berdasarkan data dan informasi yang dipalsukan oleh para pihak atau keterlibatan pejabat Notaris terhadap perbuatan melawan hukum dan Turut Serta Melakukan Kejahatan dalam pemalsuan dokumen. Berdasarkan latar belakang tersebut penulis ingin meneliti suatu kasus yang akan dibahas dalam penelitian ini yang diberi judul : "Tinjauan Yuridis Dalam Keterlibatan Pejabat Notaris Terhadap Perbuatan Melawan Hukum Dan Turut Serta Melakukan Tindak Kejahatan Dalam Pemalsuan Dokumen".

Berdasar latar belakang tersebut dapat dilakukan Perumusan masalah: 1) Bagaimana akibat keterlibatan pejabat notaris terhadap perbuatan melawan hukum dan turut serta melakukan tindak kejahatan dalam pemalsuan dokumen? 2) Bagaimana pertanggungjawaban atas keterlibatan pejabat notaris terhadap perbuatan melawan hukum dan turut serta melakukan tindak kejahatan dalam pemalsuan dokumen?

\section{Metode Penelitian}

Metode pendekatan yang digunakan adalah metode pendekatan yuridis normatif, yaitu dengan mengkaji peraturan perundang-undangan, teori-teori hukum dan yurisprudensi yang berhubungan dengan permasalahan yang dibahas.

Penelitian ini menggunakan jenis sumber data sekunder, yaitu : data yang mendukung keterangan atau menunjang kelengkapan data primer yang diperoleh dari perpustakaan dan koleksi pustaka pribadi penulis yang dilakukan dengan cara studi pustaka atau literatur.

${ }^{7}$ PAF Lamintang, 1991. Delik-delik Khusus (Kejahatankejahatan Membahayakan Kepercayaan Umum Terhadap Surat-surat, Alat-alat Pembayaran, Alat-alat Bukti dan Peradilan), Bandung : Mandar Maju, hlm. 83 
Data yang diperoleh, baik dari studi lapangan maupun studi pustaka, dianalisis secara analisis normatif, yaitu data yang terkumpul dituangkan dalam bentuk uraian logis dan sistematis, selanjutnya dianalisis untuk memeperoleh kejelasan penyelesaian masalah, kemudian ditarik kesimpulan secara deduktif, yaitu dari hal yang bersifat umum menuju ke hal yang bersifat khusus.

\section{PEMBAHASAN}

\section{Akibat Keterlibatan Pejabat Notaris Terhadap Perbuatan Melawan Hukum Dan Turut Serta Melakukan Tindak Kejahatan Dalam Pemalsuan Dokumen}

Adapun beberapa penerapan sanksi Jika notaris terbukti telah melakukan suatu pemalsuan akta otentik maka sanksi yang dapat dikenakan kepada Notaris yang melakukan pelanggaran hukum yaitu:

1. Menurut Undang-Undang Nomor 30 tahun 2004 tentang Jabatan Notaris yaitu penerapan sanksi Administratif atau Kode Etik Notaris

Secara Administratif instrumen penegakan hukum dalam Undang-Undang Jabatan Notaris, meliputi langkah preventif (Pengawasan) dan langkah represif (Penerapan sanksi). Langkah preventif dilakukan melalui pemeriksaan protocol notaris secara berkala dan kemungkinan adanya pelanggaran kode etik dalam pelaksanaan jabatan notaris. Sedangkan langkah represif dilakukan melalui penjatuhan sanksi oleh:

a. Majelis Pengawas Wilayah, berupa teguran lisan dan teguran tertulis serta berhak mengusulkan kepada Majelis Pengawas Pusat pemberhentian sementara (Tiga) 3 bulan sampai dengan (Enam) 6 bulan dan pemberhentian tidak hormat.

b. Majelis Pengawas Pusat, berupa pemberhentian sementara serta berhak mengusulkan kepada menteri berupa pemberhentian dengan tidak hormat.

c. Menteri, berupa pemberhentian dengan tidak hormat dan pemberhentian tidak hormat.

2. Menurut BW dalam Kitab Undang-Undang Hukum Perdata

Perbuatan pemalsuan akta otentik yang dilakukan oleh notaris, juga memenuhi unsur-unsur Perbuatan Melawan hukum sesuai dengan unsurunsur yang terkandung dalam pasal 1365 Kitab Undang-Undang Hukum Perdata dapat diuraikan dan dipenuhi agar suatu perbuatan itu bisa dikategorikan sebagai perbuatan melanggar hukum yaitu:

a. Harus ada Perbuatan (Daad)

b. Perbuatan itu harus melanggar hukum (Onrectmatig)
Unsur melawan atau melanggar hukum dalam kategori perdata, maka dasar terhadap unsur perbuatan melawan hukum menurut pasal 1365 Kitab Undang-Undang Hukum Perdata.

\section{Menurut Kitab Undang-Undang Hukum Pidana}

4. Sanksi pidana merupakan ultimum remedium yaitu obat terakhir, apabila sanksi atau upayaupaya pada cabang hukum lainnya tidak mempan atau dianggap tidak mempan.

Bagi notaris yang melakukan tindak pidana dapat dilakukan pemberhentian oleh Menteri dengan alasan notaris telah terbukti bersalah dan dikenakan ancaman pidana penjara, yang diatur dalam Keputusan Menteri tahun 2003 tentang Kenotariatan pasal 21 ayat (2) sub b yaitu

Notaris terbukti bersalah yang berkaitan langsung dengan jabatannya atau tindak pidana lain dengan ancaman pidana 5 (lima) tahun penjara.

Dalam Penjatuhan sanksi perdata, administratif bahkan pidana mempunyai sasaran, sifat, dan prosedur yang berbeda. Sanksi Administratif maupun Sanksi Perdata dengan sasaran yaitu perbuatan yang dilakukan oleh yang bersangkutan dan sanksi pidana dengan sasaran yaitu pelaku (orang) yang melakukan tindakan hukum tersebut.

Ketentuan Undang-Undang Nomor 2 Tahun 2014 tentang Jabatan Notaris yang menyatakan bahwa :"Isi akta tidak boleh diubah atau ditambah, baik berupa penulisan tindih, penyisipan, pencoretan, atau penghapusan dan menggantinya dengan yang lain."

Pasal 84 dan Pasal 85 Undang-Undang No. 2 Tahun 2014 tentang perubahan atas UndangUndang No. 30 Tahun 2004 tentang Jabatan Notaris diatur bahwa ketika Notaris dalam menjalankan tugas jabatannya terbukti melakukan pelanggaran, maka notaris dapat dikenai atau dijatuhi sanksi, berupa sanksi perdata, administrasi, dan kode etik jabatan Notaris, dan sanksi-sanksi tersebut telah diatur sedemikianrupa, baik sebelumnya dalam Peraturan Jabatan Notaris, dan sekarang dalam UUJN dan Kode Etik Jabatan Notaris, dan tidak mengatur adanya sanksi pidana terhadap notaris.

UUJN tidak menyebutkan adanya penerapan sanksi pidana tetapi suatu tindakan hukum terhadap pelanggaran yang dilakukan Notaris tersebut mengandung unsur-unsur pemalsuan atas kesengajaan/kelalaian dalam pembuatan akta otentik yang keterangan isinya palsu maka Notaris dapat dikenai pemidanaan.

Akan tetapi Notaris tersebut dapat dikenakan sanksi dari pasal 264 KUHP, sebab pasal 264 KUHP merupakan Pemalsuan surat yang diperberat dikarenakan obyek pemalsuan ini mengandung nilai 
kepercayaan yang tinggi. Sehingga semua unsur yang membedakan antara pasal 263 dengan pasal 264 KUHP hanya terletak pada adanya obyek pemalsuan yaitu "Macam surat dan surat yang mengandung kepercayaan yang lebih besar akan kebenaran isinya".

Rumusan pasal 264 (2) KUHP adalah sama dengan rumusan pasal 263 (2) KUHP. Perbedaannya hanya pada jenis surat yang dipakai. Pasal 263 (2) KUHP adalah surat pada umumnya, sedangkan pasal 264 (2) KUHP adalah surat-surat tertentu yang mempunyai derajat kebenaran yang lebih tinggi dan kepercayaan yang lebih besar dari surat pada umumnya. Sedangkan pelaku yang menyuruh notaris membuat akta palsu dapat dikenakan sanksi pidana pasal 266 KUHP.

Unsur kesalahan dalam kejahatan pasal 266 (1) KUHP adalah dengan maksud untuk memakai akta yang memuat kejadian palsu yang demikian itu seolah-olah keterangan dalam kata itu sesuai dengan kebenaran. Mengenai unsur kesalahan ini pada dasarnya sama dengan unsur kesalahan dalam pasal 263 (1) KUHP yang sudah diterangkan dibagian muka.

Demikian juga mengenai unsur "Jika pemakaian itu menimbulkan kerugian, sudah diterangkan secara cukup dalam pembicaraan terhadap pasal 263 dan 264 KUHP.

Mengenai kejahatan dalam ayat (2) pasal 266 pada dasarnya sama dengan kejahatan dalam ayat (2) pasal 263 dan ayat (2) pasal 264 KUHP.

Perbedaannya hanya terletak pada obyek kejahatan. Pada pasal 263 (2) KUHP yakni surat palsu dan surat dipalsu, pasal 264 (2) KUHP adalah akta-akta tertentu palsu dan akta-akta tertentu dipalsu dan pasal 266 (2) KUHP ialah akta otentik yang isinya memuat sesuatu kejadian yang palsu.

Dengan demikian pemidanaan terhadap notaris dapat saja dilakukan dengan batasan jika:

1) Ada tindakan hukum dari notaris terhadap aspek formal akta yang sengaja, penuh kesadaran dan keinsyafan serta direncanakan, bahwa akta yang dibuat dihadapan notaris atau oleh notaris bersama-sama (sepakat) untuk dijadikan dasar untuk melakukan suatu tindakan pidana;

2) Ada tindakan hukum dari notaris dalam membuat akta dihadapan atau oleh notaris yang bila diukur berdasarkan Undang-Undang Jabatan Notaris (UUJN) tidak sesuai dengan UUJN tersebut dan;

3) Tindakan notaris tersebut tidak sesuai menurut instansi yang berwenang untuk menilai suatu tindakan notaris, hal ini disebutkan dalam Majelis Pengawas Notaris ${ }^{8}$.

\section{Pertanggungjawaban Atas Keterlibatan Pejabat Notaris Terhadap Perbuatan Melawan Hukum Dan Turut Serta Melakukan Tindak Kejahatan Dalam Pemalsuan Dokumen}

Undang-Undang Nomor 30 Tahun 2004 jo Undang-Undang Nomor 2 Tahun 2014 tentang Jabatan Notaris diatur bahwa ketika Notaris dalam menjalankan tugas jabatannya telah melakukan pelanggaran yang menyebabkan penyimpangan dari hukum maka Notaris dapat dijatuhi sanksi yaitu berupa Sanksi Perdata, Administratif /Kode Etik Jabatan Notaris. Sanksi-sanksi tersebut telah diatur sedemikian rupa baik sebelumnya dan sekarang dalam Undang-Undang Jabatan Notaris terkait Kode Etik profesi Jabatan Notaris dimana tidak adanya keterangan sanksi pidana melainkan organisasi Majelis pengawas Notaris yang berkewenangan memberikan hukuman kepada notaris.

Demikian disimpulkan bahwa walaupun didalam Undang-undang jabatan notaris (UUJN) tidak menyebutkan adanya penerapan sanksi pemidanaan tetapi suatu tindakan hukum terhadap pelanggaran yang dilakukan oleh Notaris tersebut mengundang unsur-unsur pemalsuan atas kesengajaan/kelalaian dalam pembuatan surat/akta otentik yang keterangan isinya palsu maka setelah dijatuhi sanksi administratif/kode etik profesi jabatan notaris dan sanksi keperdataan kemudian dapat ditarik dan dikualifikasikan sebagai suatu tindak pidana yang dilakukan oleh Notaris yang menerangkan adanya bukti keterlibatan secara sengaja melakukan kejahatan pemalsuan akta otentik ${ }^{9}$.

Notaris memikul tanggung jawab atas setiap pekerjaan yang diberikan oleh klien kepadanya. Setiap pekerjaan akan selalu dibarengi dengan halhal yang menjadi tanggung jawabnya. Tanggung jawab menurut kamus bahasa Indonesia adalah kesadaran manusia akan tingkah laku atau perbuatannya yang disengaja maupun yang tidak disengaja ${ }^{10}$. Tanggung jawab juga berarti berbuat sebagai perwujudan kesadaran akan kewajibannya. Tanggung jawab dapat diartikan juga dengan bertindak tepat tanpa perlu diperingatkan. Sedangkan bertanggung jawab merupakan sikap tidak tergantung dan kepekaan terhadap orang lain.

\footnotetext{
${ }^{8}$ Habib Adjie, Jurnal Renvoi, Nomor 10-22 Tanggal 3 Maret 2005,hlm. 123-125

${ }_{9}$ Habib adjie, Hukum Notaris Indonesia, Bandung: Refika Aditama, 2008, hlm. 25

${ }^{10}$ Pusat Bahasa Departemen Pendidikan Nasional Republik Indonesia. Kamus Besar Bahasa Indonesia.
} 
Dapat diartikan juga bahwa tanggung jawab merupakan kesadaran yang ada pada diri seseorang bahwa setiap tindakannya akan berpengaruh terhadap orang lain ataupun pada dirinya sendiri.

Pertanggungjawaban mengandung asas kesalahan (asas culpabilitas), yang didasarkan pada keseimbangan monodualistik bahwa asas kesalahan yang didasarkan pada nilai keadilan harus disejajarkan berpasangan dengan asas legalitas yang didasarkan pada nilai kepastian. Walaupun Konsep berprinsip bahwa pertanggungjawaban pidana berdasarkan kesalahan, namun dalam beberapa hal tidak menutup kemungkinan adanya pertanggungjawaban pengganti (vicarious liability) dan pertanggungjawaban yang ketat (strict liability). Masalah kesesatan (error) baik kesesatan mengenai keadaannya (error facti) maupun kesesatan mengenai hukumnya sesuai dengan konsep alasan pemaaf sehingga pelaku tidak dipidana kecuali kesesatannya itu patut dipersalahkan ${ }^{11}$.

Diruang lingkup Notaris kita mengenal adagium bahwa "Setiap orang yang datang menghadap Notaris telah benar berkata. Sehingga benar berkata berbanding lurus dengan berkata benar". Jika benar berkata, tidak berbanding lurus dengan berkata benar yang artinya suatu kebohongan atau memberikan keterangan palsu, maka hal itu menjadi tanggungjawab yang bersangkutan. Jika hal seperti itu terjadi, maka seringkali Notaris dilaporkan kepada pihak yang berwajib dalam hal ini adalah Aparat Kepolisian. Dalam pemeriksaan Notaris dicercar dengan berbagai pertanyaan yang intinya Notaris digiring sebagai pihak yang membuat keterangan palsu. Penjatuhan sanksi pidana terhadap notaris dapat dilakukan sepanjang batasan-batasan sebagaimana tersebut diatas dilanggar, artinya disamping memenuhi rumusan pelanggaran yang disebutkan dalam Undang-Undang Jabatan Notaris (UU Perubahan atas UUJN) dan Kode Etik profesi Jabatan Notaris yang juga harus memenuhi rumusan dalam Kitab Undang- Undang Hukum Pidana (KUHP).

Dengan adanya penjelasan diatas notaris bisa saja dihukum pidana, jika dapat dibuktikan dipengadilan, bahwa secara sengaja Notaris bersama-sama dengan para pekerjanya untuk membuat akta dengan maksud dan tujuan untuk menguntungkan pihak atau penghadap dengan cara merugikan pihak penghadap yang lain. Jika hal ini terbukti maka pihak penghadap yang merugikan pihak lain beserta Notaris tersebut wajib dihukum. Notaris dapat dikatakan melakukan perbuatan

\footnotetext{
${ }^{11}$ Nawawi Arief Barda. Masalah Penegakan Hukum dan Kebijakan Penanggulangan Kejahatan, (Bandung: Citra Aditya Bakti, 2001), hlm. 23
}

penyertaan dan melakukan perbuatan melawan hukum dalam konteks Hukum Pidana sekaligus juga melanggar kode etik dan UU Perubahan atas UUJN, sehingga syarat pemidanaan menjadi lebih kuat. Apabila hal tersebut tidak disertai dengan pelanggaran kode etik atau bahkan dibenarkan oleh UU Perubahan atas UUJN, maka mungkin hal ini dapat menghapuskan sifat melawan hukum suatu perbuatan dengan suatu alasan pembenar.

Pasal 55 dan pasal 56 angka (1) dan angka (2) KUHP yang merumuskan mengenai penyertaan dalam tindak pidana dapat di kenakan kepada notaris apabila pekerja notaris melakukan tindak pidana. Penyertaan pada suatu kejahatan terdapat apabila dalam satu tindak pidana tersangkut beberapa orang atau lebih dari seorang. Hubungan tersebut ${ }^{12}$ :

1) Beberapa orang bersama-sama melakukan satu tindak pidana;

2) Mungkin hanya satu orang yang mempunyai "kehendak" dan "merencanakan" tindak pidana, akan tetapi tindak pidana tersebut tidak dilakukan sendiri, tetapi ia mempergunakan orang lain untuk melakukan tindak pidana tersebut;

3) dapat juga terjadi bahwa seorang saja yang melakukan tindak pidana, tetapi ia mempergunakan orang lain itu dalam melaksanakan tindak pidana.

Apabila setelah memberikan keterangan perihal suatu kejadian yang diminta dengan memasukkan kedalam akta otentik kepada pejabat pembuatnya, sedang akta itu sendiri belum dibuatnya atau keterangan perihal kejadiaan itu belum dimasukkan kedalam akta, kejahatan itu belum terjadi secara sempurna, melainkan baru terjadi percobaan kejahatan saja.

Obyek kejahatan ini adalah keterangan palsu, artinya suatu keterangan yang bertentangan dengan kebenaran, keterangan mana mengenai sesuatu hal/kejadian. Tidak Semua hal/kejadian berlaku disini, melainkan kejadian yang harus dibuktikan oleh akta otentik itu. Sama halnya dengan obyek surat yang diperuntukkan untuk membuktikan suatu hal dari Pasal 263 KUHP, unsur sesuatu hal dari pasal ini sama pengertiannya dengan suatu hal dari Pasal 266 KUHP itu. Suatu hal atau kejadian yang dimaksudkan adalah sesuatu hal yang menjadi isi pokok dari akta otentik yang dibuat itu.

\section{PENUTUP}

Akibat hukum bagi notaris yang melakukan pemalsuan dokumen yaitu pihak penghadap/korban mengalami derita kerugian atas terbuatnya suatu

\footnotetext{
${ }^{12}$ Didik Endro P, op.cit., hlm. 55
} 
Vol 5 No 1 Maret 2018

akta yang mengandung keterangan palsu oleh notaris. Akta palsu yang telah dibuat dapat dibatalkan. Pembatalan akta adalah menjadi kewenangan hakim perdata, yakni dengan mengajukan gugatan secara perdata kepengadilan serta menurut Undang-Undang Jabatan Notaris (UUJN) dapat dikenakan Sanksi Administratif/ Pelanggaran Kode Etik Profesi Notaris berupa teguran lisan, tertulis sampai dengan pemberhentian dengan tidak hormat dari Majelis Pengawas dan Sanksi Keperdataan pasal 1365 KUHPerdata tentang ganti kerugian.

Pertanggungjawaban pidana bagi seorang notaris apabila terbukti notaris melakukan tindak pidana pemalsuan surat maka notaris bertanggungjawab secara pribadi atas apa yang menjadi tugas serta kewenangnnya. Berkaitan dengan pertanggungjawaban pidana, seorang notaris dapat dikenakan pidana penyertaaan yang ada pada pasal 263,jo 55 dan pasal 56 angka (1) dan (2) KUHPidana, akibat kelalaiannya atas pemalsuan surat yang dilakukan oleh pekerja notaris.dengan ancaman pidana maksimal 5 tahun.

Pemerintah hendaknya memberikan pelatihan khusus terhadap notaris secara berkala agar tidak melakukan kesalahan yang fatal dimana membawa dampak pengaruh buruk yang dapat merugikan baik dari para pihak-pihak tertentu maupun diri sendiri dalam pembuatan akta otentik dan menindak secara tegas perbuatan notaris dimana diduga melakukan pelanggaran kode etik profesi notaris yang dapat dikualifikasikan dalam tersangka tindak pidana.

\section{DAFTAR PUSTAKA}

Habib Adjie, 2009, Hukum Notaris Indonesia (Tafsir Tematik Terhadap Undang-Undang Jabatan Nomor 30 Tahun 2004 Tentang Jabatan Notaris, Cetakan 2, Bandung : PT.Refika Aditama

Ira Koesoemawati dan Yunirman Rijan, 2009, Ke Notaris, Jakarta : Raih Asa Sukses (RAS)

Kie, Tan Thong. 2000. Studi Notariat Serba Serbi Praktek Notaris, Jakarta : Ichtiar Baru Van Hoeve

Mulyoto, 2010, Kesalahan Notaris dalam Pembuatan Akta Perubahan Dasar CV. Jakarta: Cakrawala Media

Nawawi Arief Barda. Masalah Penegakan Hukum dan Kebijakan Penanggulangan Kejahatan, (Bandung: Citra Aditya Bakti, 2001)

PAF Lamintang, 1991. Delik-delik Khusus (Kejahatankejahatan Membahayakan Kepercayaan Umum Terhadap Surat-surat, Alat-alat Pembayaran, Alat-alat Bukti dan Peradilan), Bandung : Mandar Maju

Pieter Latumaten, 2009, Kebatalan dan Degredasi Kekuatan Bukti Akta Notaris Serta Model Aktanya, Makalah yang disampaikan pada Kongres XX Ikatan Notaris Indonesia di Surabaya.

R. Soesilo. 1991. Kitab Undang-Undang Hukum Pidana (KUHP) Serta Komentar-Komentarnya Lengkap Pasal Demi Pasal. Jakarta : Politeia. 